\title{
Students’ Achievement Levels, Gender, and Learning Styles on Abstract Algebra: A Profile of Evidence Developing Ability
}

\author{
Leo Adhar Effendi ${ }^{1)}$, Sindi Amelia ${ }^{2)}$ \\ Mathematics Education Department, Universitas Islam Riau, Pekanbaru, Indonesia \\ e-mail: leo.ae@edu.uir.ac.id ${ }^{1)}$ \\ e-mail: sindiamelia88@edu.uir.ac.id 2)
}

\begin{abstract}
Mathematics education students' ability on developing evidence needs to be reviewed by lecturers. $50 \%$ of the subjects in the mathematics education departement require students' accuracy in analyzing mathematical statements. This is increasingly important because the Indonesian National Qualifications Framework (KKNI) for the Bachelor level requires graduates to become technicians / analysts. The diversity of levels of students' ability, gender, and learning styles are assumsed to be the discrepancy abilities to develop evidence. This study aims to describe the evidence developing ability based on the levels of achievement, gender, and student learning styles. The subjects of this study were abstact algebra students in the mathematics education department. Type of this research was descriptive qualitative with data collection techniques using test and non-test techniques. Students were given five questions about abstact algebra that demanded the evidence developing ability. The achivement levels and gender were obtained from students' academic achievement data. The learning styles were attained from questionnaires. The results of the study is higher the students' academic achievement, better the evidence developing ability on Abstract Algebra. The gender does not affect the evidence developing ability on Abstact Algebra. Students with visual learning styles have the ability to develop evidence better than students with other learning styles.
\end{abstract}

Keywords : Abstact Algebra, Achievement Levels, Evidence Developing Ability, Gender, Learning Styles

\section{INTRODUCTION}

Mathematics Education creates educators as a hand extension of mathematics into students. Mathematicians do not escape from the mathematical activities, such as: analyzing, proving, and even creating.

Mathematics education department covers several fields of subjects, including; algebra, analysis, applied, statistics, and geometry. Each subject field contains several courses. For the algebraic subjects, all mathematics education departments must include abstract algebra courses.

Abstract algebra makes mathematicians doing mathematical activities at the High Order Thinking level, which is to prove. This is reinforced by [1], he said that the approach used in the abstract algebra is reasoning, studying, analyzing, and proving that are a high level of cognitive ability. A better prove ability is one of the demands of this course.

Unfortunately, students have been accustomed and trained to counting, using formulas, or doing simple proofs. This is a cause of difficulties in lecturing abstract algebra that has a different approach of the previous subject.

The prove ability or evidence ability is not a convenience task for students. The skill to read definitions and theorems are essential key in this ability. The table 1 below 
shows the recapitulation of students' abstract algebra achievements at Mathematics Education Department FKIP UIR for the past three academic years.

Table 1. The Recapitulation of Students' Abstract Algebra Achievements

\begin{tabular}{cccc}
\hline & $\mathbf{2 0 1 4} / \mathbf{2 0 1 5}$ & $\mathbf{2 0 1 5} / \mathbf{2 0 1 6}$ & $\mathbf{2 0 1 6} / \mathbf{2 0 1 7}$ \\
\hline A Score & $48,3 \%$ & $44,0 \%$ & $7 \%$ \\
B Score & $13,8 \%$ & $32,0 \%$ & $44,4 \%$ \\
C Score & $27,6 \%$ & $20,0 \%$ & $37,04 \%$ \\
D Score & $6,9 \%$ & $0,0 \%$ & $3 \%$ \\
E Score & $3,4 \%$ & $4,0 \%$ & $8,56 \%$ \\
\cline { 2 - 3 } Source: Students' Achievements Archieve of Mathematics Education Department FKIP UIR
\end{tabular}

The achievement of the students' mathematics education FKIP UIR on abstract algebra learning above is still far from expectations. Before solving that problem, it's better for us to dig deeper into the abstract algebra itself which is reviewed from various aspects, including; level of ability, gender, and learning style .

Research conducted by [2] has resulted the significant differences in learning styles between male and female students. Male students are more likely to be convergent learning styles, while female students are more likely to be divergent learning styles. In addition, Yazici (2005) in his research about how student learning styles in team performance, has found that learning styles are influenced by learning experience, gender, and the field of study that their interests.

Knowing the profile of the students' evidence developing ability, then we know the condition of students if they have different characters, so that improving students' problems becomes more specialized. Thus, this study examines the students' evidence developing of abstract algebra when viewed in terms of students' achievement levels, gender, and learning style.

\section{RESEARCH METHOD}

This research type was qualitative research with descriptive methods. [4] revealed that the main feature of qualitative research is to analyze data for descriptions and themes using text analysis and interpreting the larger meanings of the findings. The subjects in this study were all students who took the abtract algebra course in the mathematics education department at Universitas Islam Riau in academic year 2018/2019.

The instrument provided was the questions of the evidence developing ability consisting of 5 questions. Learning style variables were measured through a questionnaire. The questionnaire was designed based on indicators of learning styles, and developed into descriptors, grids, and become learning style questionnaires.

The data analysis was conducted through the stages of data collection, data reduction, data presentation, and drawing conclusion [5]. Explanation of each stage as follows:

1. Data collection

Mathematics Research and Education Journal, Volume 4 Edisi Februari 2020 
At this stage, data on students' difficulties related to mathematical evidence obtained from the test results, the data that was not revealed through the test was deepened using interview techniques and documentation.

2. Data reduction

The data obtained in the field was selected according to the aims of the problem to be achieved. From the results of the data reduction activity, the selected data was then separated from unnecessary data. However, the unnecessary data was not removed. It means, other data revealed through data retrieval iss still considered to support the main data. Next, data on each aspect was examined.

3. Data Presentation

In this stage, the data would be presented descriptive quantitatively in the form of tables and percentages, for the aspects studied according to the identification of research.

4. Draw conclusion

Conclusions were the results of activities linking research questions with data obtained in the field.

After collecting the data, the analysis was conducted through an inductive way, bringing the data findings into the theory, the steps and analysis were as follows:

1. Identify students' difficulties in mathematical evidence.

2. Identify students' mathematical proofing abilities.

3. Draw conclusions.

\section{FINDINGS AND DISCUSSION}

In the results, information was obtained that the students' evidence developing ability as a whole, the evidence developing ability based on students' achievement levels, gender, and the learning styles. The results obtained are as follows:

Table 2. The Students' Evidence Developing Ability for Overall

\begin{tabular}{cccccccc}
\hline & \multicolumn{2}{c}{ Indicator 1 } & \multicolumn{2}{c}{ Indicator 2 } & \multicolumn{3}{c}{ Indicator 3 } \\
\cline { 2 - 8 } & Question & Question & Question & Question & Question & Question & Question \\
& $\mathbf{1}$ & $\mathbf{2}$ & $\mathbf{1}$ & $\mathbf{2}$ & $\mathbf{3}$ & $\mathbf{4}$ & $\mathbf{5}$ \\
\hline $\mathbf{f}$ & 23 & 12 & 7 & 6 & 4 & 2 & 17 \\
$\mathbf{N}$ & 73 & 73 & 73 & 73 & 73 & 73 & 73 \\
$\mathbf{\%}$ & 31.51 & 16.44 & 9.59 & 8.22 & 5.48 & 2.74 & 23.29 \\
\hline
\end{tabular}

In general, the data shows the evidence developing ability of students is still very weak and no more than two-thirds of the total number of research subjects, failed to do proof. The indicator that has the greatest achievement is reading a proof of mathematics to determine the truth or error by looking at the compatibility among the axiom system, the premise, and existing mathematical results (entries or theorems), with the flow of deductive reasoning (Indicator 1).

Mathematics Research and Education Journal, Volume 4 Edisi Februari 2020 
However, after being success in determining right or wrong from proof, only few students had succeeded in improving/completing the evidence (Indicator 2), which is around $8-10 \%$ of students. While in indicator 3, almost a quarter of the total subjects research succeed in answering question number 5 , but question number 4 is the most difficult for students because only $2.74 \%$ of students answered correctly.

Table 3. Evidence Developing Ability Based on Students' Achievement Levels

\begin{tabular}{ccccccccc}
\hline \multirow{2}{*}{$\begin{array}{c}\text { Students' } \\
\text { Achievement Levels }\end{array}$} & \multicolumn{2}{c}{ Indicator 1 } & \multicolumn{3}{c}{ Indicator 2 } & \multicolumn{3}{c}{ Indicator 3 } \\
\cline { 2 - 9 } Low & $\mathbf{Q}$ & 6 & 3 & 1 & 1 & 0 & 0 & 4 \\
& $\mathbf{N}$ & 20 & 20 & 20 & 20 & 20 & 20 & 20 \\
& $\mathbf{\%}$ & 30 & 15 & 5 & 5 & 0 & 0 & 20 \\
\multirow{4}{*}{ Middle } & $\mathbf{f}$ & 9 & 4 & 1 & 3 & 1 & 0 & 8 \\
& $\mathbf{N}$ & 33 & 33 & 33 & 33 & 33 & 33 & 33 \\
& $\mathbf{\%}$ & 27.27 & 12.12 & 3.03 & 9.09 & 3.03 & 0.00 & 24.24 \\
\multirow{4}{*}{ High } & $\mathbf{f}$ & 8 & 5 & 5 & 2 & 3 & 2 & 5 \\
& $\mathbf{N}$ & 20 & 20 & 20 & 20 & 20 & 20 & 20 \\
& $\mathbf{\%}$ & 40 & 25 & 25 & 10 & 15 & 10 & 25 \\
\hline
\end{tabular}

According to the table, it can be seen that the higher students' academic ability tends to have the better evidence developing ability. On each indicator, the evidence developing ability of students with middle academic abilities is better than low academic abilities'. Likewise, students with high academic abilities are better than students with middle academic abilities.

Like the students' evidence developing ability data for overall (Table 2), students grouped into three different levels (high, middle, and low) also assumed that the question number 1 on indicator 1 was an convenient question to answer even though the score does not reach $50 \%$, followed by question number 5 on indicator 3 which ranges from $20 \%$ to $25 \%$ of the total students involved in this study. Although, for questions number 3 and number 4 on indicator 3, high category students were able to answer correctly by $10-15 \%$, while low category students did not answer correctly. Besides, students in the middle category only managed to answer for the number questions 3 with a percentage of 3.03\%.

Table 4. Evidence Developing Ability Based on Gender

\begin{tabular}{lcccccccc}
\hline \multirow{2}{*}{ Gender } & & \multicolumn{2}{c}{ Indicator 1 } & \multicolumn{3}{c}{ Indicator 2 } & \multicolumn{3}{c}{ Indicator 3 } \\
\cline { 2 - 10 } & & Q 1 & Q 2 & Q 1 & Q 2 & Q 3 & Q 4 & Q 5 \\
\hline \multirow{3}{*}{ Male } & $\mathrm{f}$ & 4 & 1 & 2 & 1 & 0 & 0 & 0 \\
& $\mathrm{~N}$ & 10 & 10 & 10 & 10 & 10 & 10 & 10 \\
& $\%$ & 40 & 10 & 20 & 10 & 0 & 0 & 0 \\
\hline
\end{tabular}

Mathematics Research and Education Journal, Volume 4 Edisi Februari 2020 


\begin{tabular}{ccccccccc}
\hline \multirow{3}{*}{ Female } & $\mathrm{f}$ & 19 & 11 & 5 & 5 & 4 & 2 & 17 \\
& $\mathrm{~N}$ & 63 & 63 & 63 & 63 & 63 & 63 & 63 \\
& $\%$ & 30.16 & 17.46 & 7.94 & 7.94 & 6.35 & 3.17 & 26.98 \\
\hline
\end{tabular}

In general, male students have the evidence developing ability, especially on indicators 1 and 2, tend to be better than female students'. Whereas in indicator 3, female students are better than male students.

Of the five abstract algebra questions and the three indicators were given, male students attain the highest percentage at $40 \%$ for question number 1 on indicator $1,10 \%$ less than that of female students'. Nevertheless, on indicator 3, male students did not succeed in answering the three questions given, whereas female students were able to answer the questions with a range of percentage at 3-26\%.

Based on the data above, it can be concluded that gender does not affect the tendency of the students' evidence developing ability in the abstract algebra course.

Table 5. Evidence Developing Ability Based on Learning Styles

\begin{tabular}{|c|c|c|c|c|c|c|c|c|}
\hline \multirow{2}{*}{$\begin{array}{c}\text { Learning Style } \\
\text { Tendency }\end{array}$} & & \multicolumn{2}{|c|}{ Indicator 1} & \multicolumn{2}{|c|}{ Indicator 2} & \multicolumn{3}{|c|}{ Indicator 3} \\
\hline & & Q 1 & Q 2 & Q 1 & Q 2 & Q 3 & Q 4 & Q 5 \\
\hline \multirow[t]{3}{*}{ Visual } & $\mathrm{f}$ & 5 & 4 & 1 & 1 & 1 & 1 & 2 \\
\hline & $\mathrm{N}$ & 10 & 10 & 10 & 10 & 10 & 10 & 10 \\
\hline & $\%$ & 50 & 40 & 10 & 10 & 10 & 10 & 20 \\
\hline \multirow[t]{3}{*}{ Auditory } & $\mathrm{f}$ & 9 & 2 & 3 & 1 & 2 & 0 & 9 \\
\hline & $\mathrm{N}$ & 28 & 28 & 28 & 28 & 28 & 28 & 28 \\
\hline & $\%$ & 32.14 & 7.14 & 10.71 & 3.57 & 7.14 & 0.00 & 32.14 \\
\hline \multirow[t]{3}{*}{ Kinesthetic } & $\mathrm{f}$ & 5 & 5 & 2 & 4 & 1 & 0 & 3 \\
\hline & $\mathrm{N}$ & 24 & 24 & 24 & 24 & 24 & 24 & 24 \\
\hline & $\%$ & 20.83 & 20.83 & 8.33 & 16.67 & 4.17 & 0.00 & 12.50 \\
\hline \multirow{3}{*}{$\begin{array}{l}\text { Visual and } \\
\text { Auditory }\end{array}$} & $\mathrm{f}$ & 3 & 0 & 1 & 0 & 0 & 0 & 3 \\
\hline & $\mathrm{N}$ & 5 & 5 & 5 & 5 & 5 & 5 & 5 \\
\hline & $\%$ & 60 & 0 & 20 & 0 & 0 & 0 & 60 \\
\hline \multirow{3}{*}{$\begin{array}{l}\text { Visual and } \\
\text { Kinesthetic }\end{array}$} & $\mathrm{f}$ & 0 & 0 & 0 & 0 & 0 & 1 & 0 \\
\hline & $\mathrm{N}$ & 2 & 2 & 2 & 2 & 2 & 2 & 2 \\
\hline & $\%$ & 0.00 & 0.00 & 0.00 & 0.00 & 0.00 & 50.00 & 0.00 \\
\hline \multirow{3}{*}{$\begin{array}{l}\text { Auditory and } \\
\text { Kinesthetic }\end{array}$} & $\mathrm{f}$ & 1 & 1 & 0 & 0 & 0 & 0 & 0 \\
\hline & $\mathrm{N}$ & 3 & 3 & 3 & 3 & 3 & 3 & 3 \\
\hline & $\%$ & 33.33 & 33.33 & 0.00 & 0.00 & 0.00 & 0.00 & 0.00 \\
\hline \multirow{3}{*}{$\begin{array}{l}\text { Visual, Auditory, } \\
\text { and Kinesthetic }\end{array}$} & $\mathrm{f}$ & 0 & 0 & 0 & 0 & 0 & 0 & 0 \\
\hline & $\mathrm{N}$ & 1 & 1 & 1 & 1 & 1 & 1 & 1 \\
\hline & $\%$ & 0 & 0 & 0 & 0 & 0 & 0 & 0 \\
\hline
\end{tabular}


Table 5 provides information about the proportion of seven students' learning styles-visual, auditory, kinesthetic, visual and auditory, visual and kinesthetic, auditory and kinesthetic, and visual, auditory, and kinesthetic-in solving the question of the evidence developing ability.

According to the data, students with visual learning styles tend to have the evidence developing ability better than students with other learning styles. Meanwhile, the highest achievement of students in developing evidence is found in students with visual and auditory learning styles at $60 \%$ in question number 1 on indicator 1 . For question number 4 on indicator 3 can only be solved by students who have visual and kinesthetic learning styles at $50 \%$, followed by just students with visual learning styles, $40 \%$ less than that of students who use visual and kinesthetic learning styles simultaneously. Whereas the other learning styles (auditory, kinesthetic, visual and auditory, auditory and kinesthetic, and the combination of visual, auditory, and kinesthetic) are not successful in answering question number 4 on indicator 3 .

Compared with auditory learning styles, the students' evidence developing ability with kinesthetic learning styles tends to be better. Students who have a kinesthetic learning style are only lower on indicator 3, which is writing proof clearly, completely and systematically.

\section{Discussion}

In question number 1, generally, students answered that the proof given was correct. Based on the picture below, it can be seen that students are wrong in analyzing the evidence. They failed to analyze that not all $y \in \mathbb{R}, \exists x \in \mathbb{R}$ so that $f(x)=y$. For example for $y=-4$ obtained $x=\sqrt{\frac{-1}{2}} \notin \mathbb{R}$.

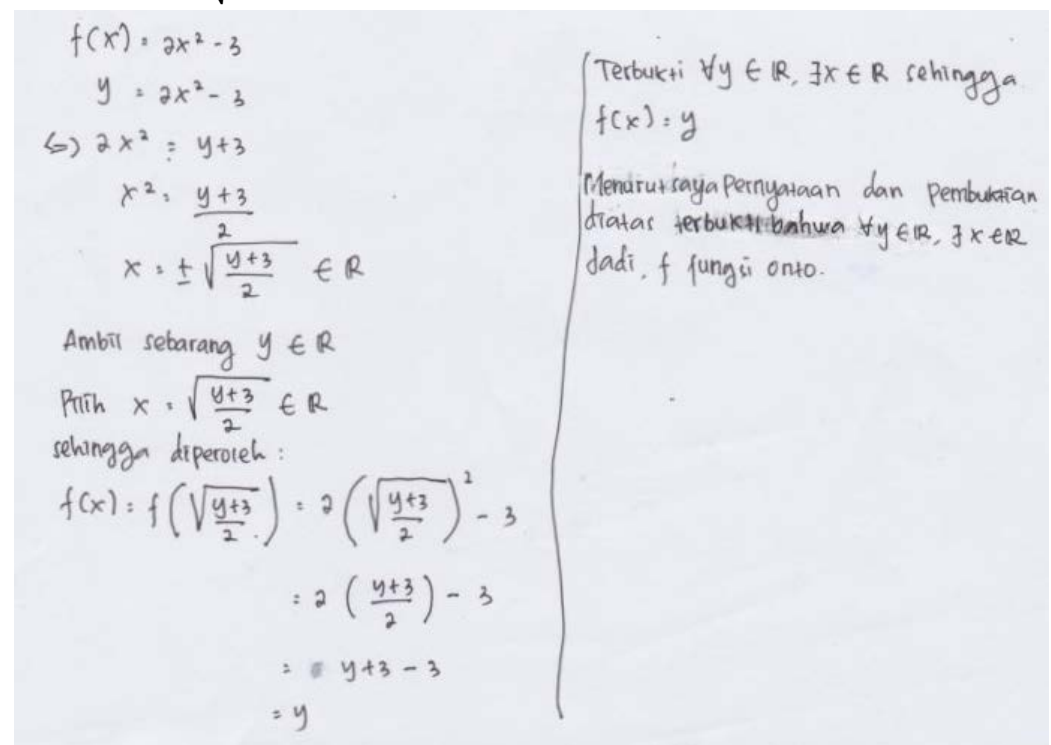

Figure 1. Students’ Error in Analyzing the Question Number 1

Mathematics Research and Education Journal, Volume 4 Edisi Februari 2020 
In question number 2, mistakes made by students generally answered that the proof given was correct. They answered that $\forall a, b \in \mathbb{N}, a * b=2 a+b-a b \in \mathbb{N}$. Even though, there were $a=3$ and $b=4$, so that $* b=3 * 4=2.3+4-3.4=-2 \notin \mathbb{N}$.

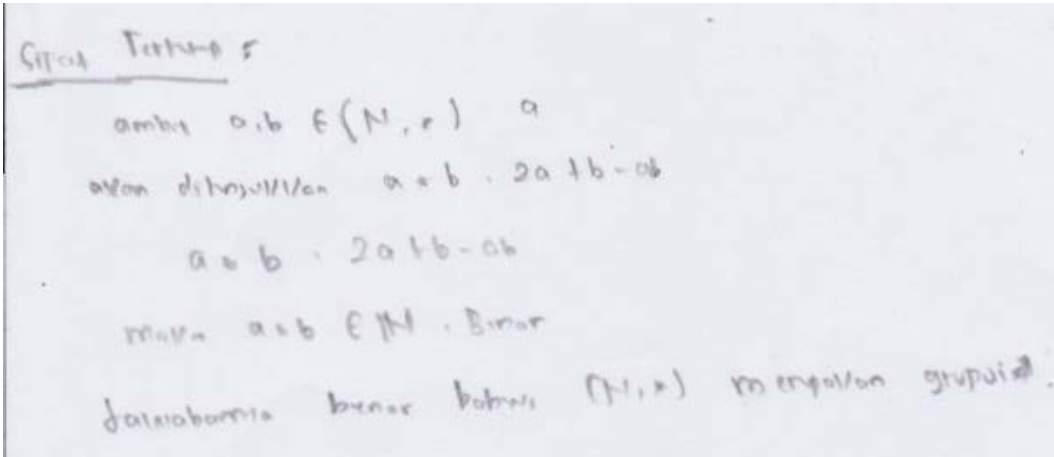

Figure 2. Students’ Error in Analyzing the Question Number 2

Furthermore, some students have compiled the evidences using examples. To prove a true statement cannot be done by taking an example. The examples can only be used for proof as a denial of a statement, commonly known as the counter example.

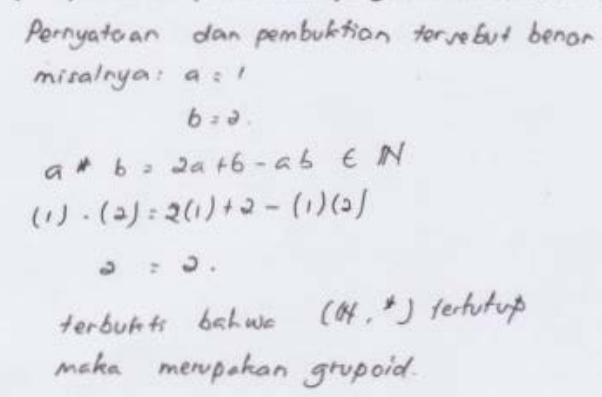

Figure 3. Students' Error in Analyzing the Question Number 2 (2)

In question number 3, a big proportion of the students did not succeed in finding the identity of the abstract algebra given. They were difficult using the nature of identity in complex abstract algebra.

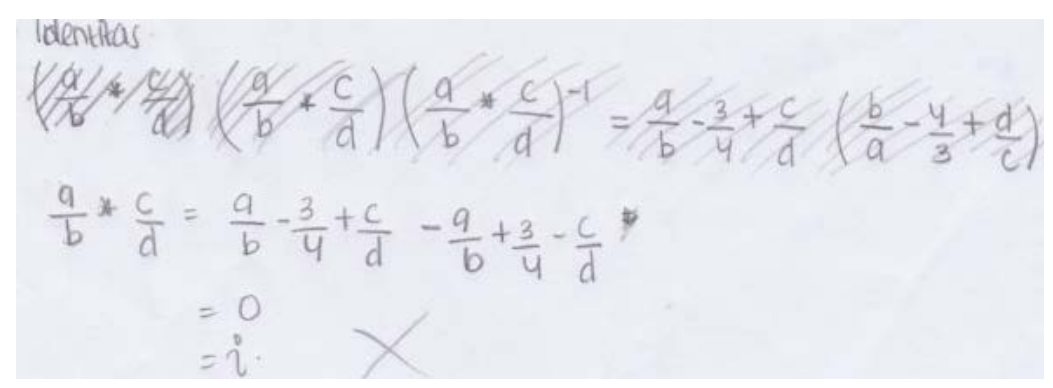

Figure 4. Students' Error in Analyzing the Question Number 3

Mathematics Research and Education Journal, Volume 4 Edisi Februari 2020 
Moreover, an error concept was also found for identity and inverse materials. If it was not exchanged between identity and inverse, then this proof would be correct at the identity point. Thus, the inverse concept was also correct, yet the students couldnot find the inverse.

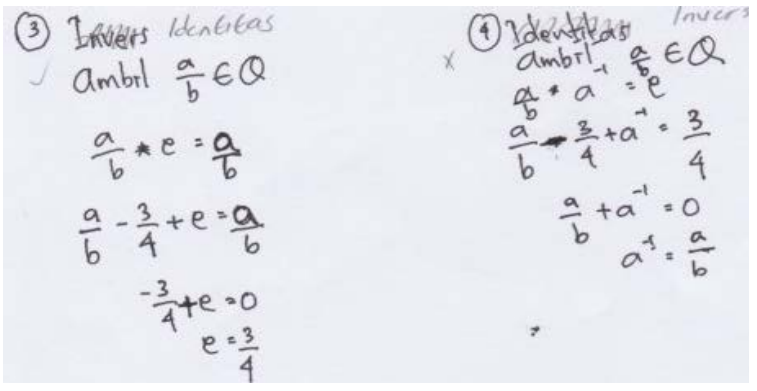

Figure 5. Students’ Error in Analyzing the Question Number 3 (2)

In question number 4, students' mistakes were caused by difficulties using the premise $g=g^{-1}, \forall g \in G$. This would not happen if they remembered the concept $(a * b)^{-1}=b^{-1} * a^{-1}$ in the group.

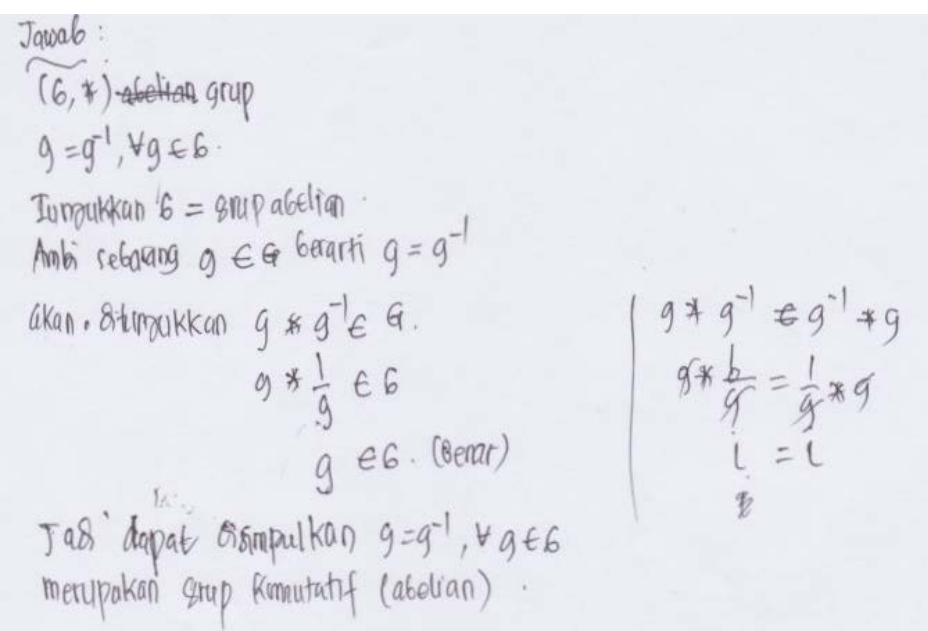

Figure 6. Students' Error in Analyzing the Question Number 4

In question number 5, students' mistakes were generally caused by students having difficulty using the theorem which is the basis of proof. In part (ii), it should not be written as I (identity) but any element of $\mathrm{H}$. 


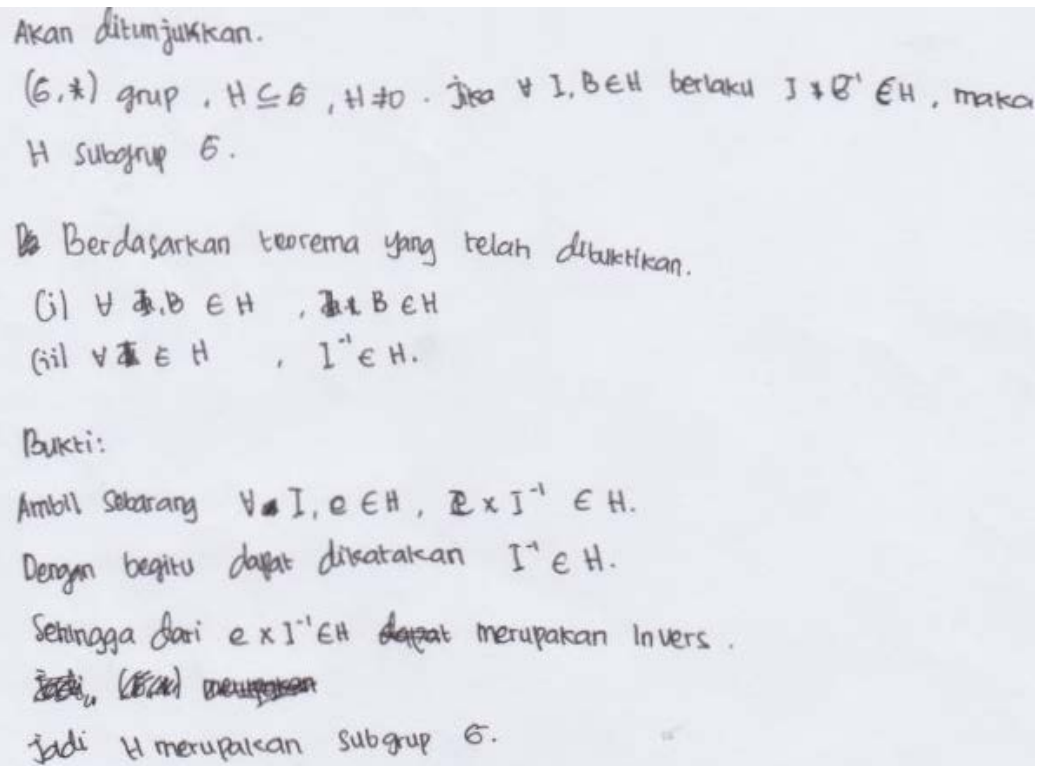

Figure 7. Students’ Error in Analyzing the Question Number 5

From the results of the research that has been described, from the three factors, namely achievement levels, gender, and learning styles, the achievement level and learning style factors provide the different trends in the evidence developing ability on abstract algebra course. Gender does not provide a difference tendency of the evidence developing ability on abstract algebra course. This is not seen because the number of male students is very unequal to women.

\section{CONCLUTIONS}

From the results and discussion of the research can be summarized as follows.

1. The students' evidence developing ability on abstract algebra course is still very weak.

2. The higher the achievement levels of students, then better of the evidence developing ability on abstract algebra course.

3. Gender does not affect the tendency of the students' evidence developing ability on abstract algebra course.

4. Students with visual learning styles have the evidence developing ability better than students with other learning styles.

\section{REFERENCES}

[1] Salsabila, E., \& Hadi, I. (2015). Pembekalan Pemahaman Metode Pembuktian Matematika dan Penerapan Strategi Abduktif-Deduktif untuk Mengembangkan Kemampuan Membuktikan Konsep Aljabar Abstrak pada Mahasiswa Jurusan Matematika FMIPA UNJ. Jurnal Matematika Integratif, 11(1), 15-24.

Mathematics Research and Education Journal, Volume 4 Edisi Februari 2020 
[2] BuAli, W. H., Balaha, M. H., \& Muhaidab, N. S. (2013). Assessment of Learning Style in a Sample of Saudi Medical Students. Journal of Academy of Medical Sciences of Bosnia and Herzegovina, 21(2), 83-88. doi: 10.5455/aim.2013.21.83-88

[3] Yazici, H. J. (2005). A Study of Collaborative Learning Style and Team Learning Performance. Education $\quad+\quad$ Learning, 47(3), 216-229. https://doi.org/10.1108/00400910510592257

[4] Creswell, J. (2015). Riset Pendidikan: Perencanaan, Pelaksanaan, dan Evaluasi Riset Kualitatif \& Kuantitatif. (H. P. Soetjipto, \& S. M. Soetjipto, Trans.) Yogyakarta: Pustaka Pelajar.

[5] Ulya, H. (2016). Profil Kemampuan Pemecahan Masalah Siswa Bermotivasi Belajar Tinggi Berdasarkan Ideal Problem Solving. Jurnal Konseling Gusjigang, 2(1). 